\title{
Modeling Exchange Rate Volatility in the Presence of Serial Correlations
}

\author{
Emmanuel Dodzi Kutor Havi, M.Phil. \\ Methodist University College Ghana, Ghana
}

Doi: 10.19044/elp.v6no4a2

URL:http://dx.doi.org/10.19044/elp.v6no4a2

\begin{abstract}
The objective of this study was to model the volatility in GHC/US\$ exchange rate series taking into consideration the presence of serial correlation. The data used was GHC/US\$ exchange rate from January 2000 to August 2019. To select appropriate model for modeling volatility $\operatorname{GARCH}(p, q), \operatorname{TARCH}(p, q) \operatorname{EGARC}(p, q), \operatorname{PARCH}(p, q)$ and $\operatorname{APARCH}(p, q)$ were estimated and evaluated. The ARMA(3,3)-TARCH(2,1)-GED was selected as the appropriate model. It was found out that the return series had serial correlation problem. It was found that heteroscedasticity was present and was captured by $\operatorname{ARMA}(3,3)-\mathrm{TARCH}(2,1)$ model under general error distribution but could not account for the serial correlation in the return series. However, the corresponding GARCH-M-TARCH $(2,1)$ model under general error distribution sufficiently captured the presence of serial correlation. From the results when the existence of serial correlations were ignored in the return series the parameters estimated will be bias and inefficient. Hence, the application of GARCH-M types of models provided possible feedback between the variance and the mean equations. It was also found out that previous information about volatility and the previous volatility had significant effect on the current day volatility. From the result there was no leverage effect and the impact of news was asymmetric.
\end{abstract}

Keywords: Exchange rate; serial correlations; volatility; GARCH-in-MeanGARCH-type.

\section{Introduction}

The exchange rate movements and fluctuations over the past few years had become very important issue among economists, financial analyst and policy makers. More importantly, after the collapse of the Bretton Wood agreement of fixed exchange rates among major industrial nations. Exchange rate volatility is the risk associated with the unexpected movement in the exchange rate; that is, the risk associated with currency depreciation or 
appreciation over time. Since the collapse of fixed exchange rate, the issue of volatility of exchange rate and its influence on wellbeing and some macroeconomics variables and competitiveness of the economy in the world market. Also, the role it plays in security valuation; investment and profitability and risk analysis. As a result, various models had been developed to investigate this volatility across different nations and regions.

In the recent past the issue of modelling volatility in exchange rate has become very important as more countries shifted to flexible exchange rate regime. In modeling volatility on returns of exchange rates, analyst most often assumed that the series of the financial variable do not have serial correlation. However, it has been observed that financial variables with very small period between observations may have a significant autocorrelation; a relationship that exist between or among a variable and its lagged-value over a period of time. Therefore, this study aimed at investigating the existence of serial correlations in the effective exchange rate of the Ghana Cedis to the US Dollar, GHC/US\$ series and also its effect on the parameter estimates of volatility model. This paper aimed at modelling the volatility in exchange rate of the GHC/US\$ series considering high frequency daily and monthly observations. The following research questions will be used to guide the study.

- Does serial correlations exist in the GHC/US\$ series?

- Which of the GARCH(p,q) best model volatility in the GHC/US\$ series?

- Does serial correlation affect the parameters estimated?

Also, to guide the study the following hypotheses will be tested:

$\mathrm{H}_{0}$ : Serial correlations do not exist in the GHC/US\$ series.

$\mathrm{H}_{1}$ : Serial correlations do exist in the GHC/US\$ series.

$\mathrm{H}_{0}$ : The serial correlation does not affect the parameters of the estimates.

$\mathrm{H}_{1}$ : The serial correlation affects the parameters of the estimates.

Decision Rule: Accept the alternative hypothesis if the p-value associated with a parameter is less than or equal to 0.05 otherwise reject the alternative hypothesis.

The findings from this study will be useful for dealers in the exchange rate like the banks, import and export traders.

The rest of the study will be organized as follows, the review of literatures will be discussed in section two. Section three will present the methods used while section four will present the results and discussion. Finally, the conclusion and recommendations will be presented in section five.

\section{Literature Review}

Issues of exchange rate volatility has remained very vital because of its implications on individual and cooperate transactions as well as national 
policies. However, most researchers investigating volatility in financial variables, for example exchange rate, ignore the existence of serial correlation or autocorrelation in the return series generated. Some of the articles related to the current issue are reviewed below.

The conditional heteroscedasticity of the Yen against Dollar exchange rate was examined by Tse (1998). In this study a model was constructed by extending the APARCH model to a process that is fractionally integrated. It was found that, the appreciation and depreciation shocks of the yen against the dollar have similar effects on future volatilities. Although, the results rejected both the stable and the integrated models, the analysis of the response coefficients of the past shocks and the application of the models to the estimation of the capital requirements for trading the currencies showed that there were no substantial differences between both models estimated.

In the same vein, Clement \& Samuel (2011) modelled the volatility persistence and asymmetry of naira-dollar exchange rate in interbank and Bureau de Change (BDC) using monthly data between January 2004 and November 2017. The study employed $\operatorname{GARCH}(1,1)$, TGARCH $(1,1)$ and EGARCH(1,1)]. The findings showed that persistence was generally explosive in the BDC market as compared to interbank market where the persistence was high but not explosive especially under asymmetric models. Based on the model selection criteria, the symmetric GARCH model, appears to be better than the asymmetric ones in dealing with exchange rate volatility in the interbank market while asymmetric GARCH, especially TGARCH, seems to be better in the case of BDC market.

Also, Alam (2012) explored the application of GARCH type models to model the BDT against US dollar using daily exchange rate published by the Bank of Bangladesh. The study used AR and ARMA models as benchmark. The exchange rate from July 03, 2006 to April 30, 2012 was used. For the purpose of the study observations from July 03, 2006 to May 13, 2010 and May 14, 2012 to April 30, 2012 for in-sample and out-of-sample, respectively. The finding showed that in the GARCH models the previous had significant impact on the current volatility. Both AR and ARMA models were better in in-sample performance while $\operatorname{TGARCH}(1,1)$ was better in out-ofsample with transaction costs. The $\operatorname{EGARCH}(1,1)$ and $\operatorname{TGARCH}(1,1)$ were best in in-sample and out-of-sample trading performance, respectively, including transaction costs.

Ramasamy \& Munisamy (2012) compared 2) compares three simulated exchange rates of Malaysian Ringgit with actual exchange rates using GARHC, GJR and EGARCH models. For testing the forecasting effectiveness of GARCH, GJR and EGARCH the daily exchange rates for four currencies viz Australian Dollar, Singapore Dollar, Thailand Bhat and Philippine Peso are used. The forecasted rates, using Gaussian random 
numbers, are compared with the actual exchange rates of year 2011 to estimate errors. Both the forecasted and actual rates are plotted to observe the synchronisation and validation. The results showed more volatile exchange rates were predicted well by these GARCH models efficiently than the hard currency exchange rates which were less volatile. Among the three models the effective model is indeterminable as these models forecast the exchange rates in different number of iterations for different currencies. The leverage effect incorporated in GJR and EGARCH models did not improve the results much.

Finally, Moffat \& Akpan (2019) modeled heteroscedasticity of returns taking into consideration the presence of serial correlations. The study used stock prices from the Nigeria Stock Market from January 3, 2006 to November 24, 2016. The ARIMA-GARCH-type models such as ARIMA-GARCH, ARIMA-EGARCH and ARIMA- GJRGARCH using normal and student's distributions. Also, the GARCH-M-GARCH model corresponding to the selected model was used to capture the presence of autocorrelation. From the result, the presence of heteroscedasticity was confirmed and well capture by $\operatorname{ARIMA}(2,1,1)$-EGARCH$(1,1)$ with student-t distribution, but failed to account for the existence of serial correlation in the return series. However, the corresponding GARCH-M-EGARCH(1,1) account significantly for the serial correlation.

From the above empirical studies the issue of serial correlation was ignored except Moffat \& Akpan (2019). However, when serial correlation is present in the return series but ignored in the estimation process according to Zhao, el al. (2014) the parameter estimates becomes bias and inefficient. For that matter when GARCH results are compared with other output like AR or ARIMA as the case in Alam (2012), the AR or ARIMA turned to outperform the GARCH results because the parameters from the GARCH model might had been bias. Therefore, this study used Ghanaian high frequency daily and monthly exchange rate from January 2000 to August 2019 to investigate the effect of serial correlation on the parameter estimates of the exchange rate volatility. This study will contribute to knowledge on modeling exchange rate volatility. The result will be useful to exchange rate dealers who might have been using bias estimates previously for their works.

\section{Methodology}

The presence of serial correlations in most financial variables are ignored when analyzing such series. However, according to Tsay (2010) the presence of serial correlation in the financial variables was the result of time varying heteroscedasticity process. Also, according to Zhao, el al. (2014) if the serial correlations are not taken into consideration when modelling the parameters estimated will be bias. Therefore, to account for the serial correlation in modelling volatility, Engle, el al. (1987) proposed the modification of standard GARCH type models assuming that the variance coefficient in the mean equation measures relative risk aversion. This 
modification to standard GARCH model is referred to as GARCH-in-Mean model. It allowed the conditional variance of the returns series to have impact on the conditional mean.

The data used in this study was daily and monthly exchange rate, GHCUS\$, from January 2000 to August 2019, Bank of Ghana's database (www.bog.gov.gh). Since the nominal exchange rates series are nonstationary, it will be converted by logarithmic transformation into rate of return on the exchange rate as shown in equation [1] below. In this case, let $E_{t}, t=1,2, \ldots, n$, be the exchange rate, therefore, the log-return $\left(R_{t}\right)$ on $E_{t}$ is expressed as:

$$
R_{t}=\ln \left(E_{t}\right)-\ln \left(E_{t-1}\right)
$$

The mean equation formed is shown equation [2] below and various specifications of the mean equation will be estimated and tested for the presence of heteroscedasticity. The mean equation in this study is specified as;

$$
R_{t}=c+a_{1} A R(1)+k_{1} M A(1)+\ldots+a_{i} A R(i)+k_{i} M A(i)+e_{t}
$$

where $c$ is constant term, $i$ is the optimal lag of ARMA (Autoregressive Moving Average) term that makes coefficients significant, $a_{i}$ and $k_{j}$ are coefficients of the ARMA terms, respectively, and $e_{t}$ - error term. To select appropriate model for volatility persistence and asymmetric effect $\operatorname{GARCH}(p, q), \quad \operatorname{TARCH}(p, q)$ and $\operatorname{EGARCH}(\mathrm{p}, \mathrm{q}), \operatorname{PARCH}(\mathrm{p}, \mathrm{q})$ and $\operatorname{APARCH}(p, q)$ will be used and their specifications are stated below.

\section{The Generalized Autoregressive Conditional Heteroscedasticity, $\operatorname{GARCH}(\mathbf{p}, \mathbf{q})$}

Bollerslev (1986) and Taylor (1986) introduced GARCH model that allows conditional variance to depend on its own previous lags and previous lag of square residuals of the mean equation. It is specified as: $\sigma_{t}^{2}=\omega+\sum_{i=1}^{p} \alpha_{i} e_{t-i}^{2}+\sum_{j i=1}^{q} \beta_{j} \sigma_{t-j}^{2}+\mu_{t}$

where $\sigma_{t}^{2}-$ conditional variance or current day/month's variance of conditional volatility of exchange rate return, $\sigma_{t-j}^{2}$ - previous day/month's conditional variance or the GARCH term., $\mathrm{e}_{\mathrm{t}-\mathrm{i}}^{2}$ - previous day/month's news about conditional volatility or the ARCH term, $\omega$ - constant term, $\alpha_{i}-$ coefficient of ARCH term and $\beta_{j}$ - coefficient of GARCH term. For the variance to remain well behaved $\alpha_{i} \geq 0$ and $\beta_{j} \geq 0$, also, the sum of coefficient of ARCH and GARCH terms should be less than one; $\alpha_{i}+\beta_{j}<1$ to ensure that the series is stable and the variance is positive. 


\section{The Threshold GARCH, TARCH(p, $q)$}

The TGARCH was introduced by Zakoan (1994) and Glosten et al (1993) to analyze the leverage effect and it is specified as;

$$
\sigma_{t}^{2}=\omega+\sum_{i=1}^{p} \alpha_{i} e_{t-i}^{2}+\sum_{k=1}^{r} \lambda_{k} d_{t-k} e_{t-k}^{2}+\sum_{j i=1}^{q} \beta_{j} \sigma_{t-j}^{2}+\mu_{t} \ldots \ldots \ldots \ldots \ldots \ldots
$$

where $d_{t-k}=1$ if $e_{t-i}<0$ and zero otherwise. In this model, good news, $e_{t-i}>0$ and bad news $e_{t-i}<0$, have different effect on the conditional variance. Good news has impact of $\alpha_{i}$ while bad news has impact of $\alpha_{i}+\lambda_{k}$. If $\lambda_{k}>0$, it means bad news increase volatility hence leverage effect, if $\lambda_{k} \neq 0$, the news impact is asymmetric.

\section{The Exponential GARCH, EGARCH $(p, q)$}

The EGARCH model was proposed by Nelson(1991) and was specified as:

$$
\log \left(\sigma_{t}^{2}\right)=\omega+\sum_{i=1}^{p} \alpha_{i}\left|\frac{e_{t-i}}{\sigma_{t-i}}\right|+\sum_{k=1}^{r} \gamma_{k} \frac{e_{t-i k}}{\sigma_{t-k}}+\sum_{j i=1}^{q} \beta_{j} \log \left(\sigma_{t-j}^{2}\right)+\mu_{t}
$$

where $\log \mathrm{H}_{\mathrm{t}}^{2}$ - the natural logarithm of conditional variance, $\log \left(\mathrm{H}_{\mathrm{t}-1}^{2}\right)-$ previous day's natural $\log$ of conditional variance, $\omega$-constant term, $\alpha-$ parameter represents a magnitude effect; $\gamma$ - parameter measures the asymmetric or the leverage effect. If $\gamma=0$, then the model is symmetric; if $\gamma<0$, there is presence of leverage effect; finally, if $\gamma>0$, the impact is asymmetric, $\beta$ - measures the persistence in conditional volatility irrespective of what is happening in the foreign exchange rate market.

\section{Power ARCH, PARCH(p,q)}

Taylor(1986) and Schwert(1989) introduced the standard deviation form of GARCH model, where standard deviation was modelled rather than the variance. This model with other forms of specifications were generalized in Ding et al (1993) with power ARCH (PARCH) specification. In PARCH specification there is optional parameter added to capture asymmetry of up to order r:

$$
\sigma_{t}^{\delta}=\omega+\sum_{i=1}^{p} \alpha_{i}\left(\left|e_{t-i}\right|-\gamma_{i} e_{t-i}\right)^{\delta}+\sum_{j i=1}^{q} \beta_{j} \sigma_{t-j}^{\delta}+\mu_{t}
$$

where $\delta>0$, for $\gamma_{i} \leq 1$, for all $i=1, \ldots, r, \gamma_{i}=0$, for all $i>r$ and $r \leq p$. For a symmetric model, $\gamma_{i}=0$, for all $i$ while asymmetric effects are present if $\gamma \neq 0$ 


\section{GARCH-in-Mean, GARCH-M, Model}

The mean equation [2] is modified to obtain GARCH-M model in equation [7] such that the return series is influenced by the conditional variance. According to Tsay(2010) this specification implies that there are serial correlation in the series.

$$
R_{t}=c+b \sigma^{2}+a_{i} A R(i)+k_{j} M A(j)+e_{t}
$$

Where the parameter $b$ is variance coefficient. The significance of the variance coefficient shows that the returns series has serial; the return series is related to its variance.

\section{Model Evaluation}

The error term from the variance equations estimated will be evaluated based on heteroscedasticity, serial correlation and normality tests. For good model the residual should not have serial correlation, should be homoscedastic and finally it should be normally distributed. But the error term from the GARCH results are usually not normally distributed. Therefore, for a model to be selected for estimation has to pass the test of serial correlation and heteroscedasticity. Hence, the following hypotheses will be tested at 5 percent level of significance on the error term of the various variance equations estimated. Firstly, the serial correlation will be tested using a correlogram of squared residuals.

$\mathrm{H}_{0}$ : There is no serial correlation in the error term.

$\mathrm{H}_{1}$ : There is serial correlation in the error term.

Also, the heteroscedasticity will be tested using an ARCH-LM test, the Chisquare and the corresponding probability will be examined.

$\mathrm{H}_{0}$ : There is no ARCH affect or there is no heteroscedasticity.

$\mathrm{H}_{1}$ : There is ARCH affect or there is heteroscedasticity.

Finally, histogram-normality test will be used to check the normality of the residual terms. Jarque-Bera statistics with the corresponding p-value will be examined.

$\mathrm{H}_{0}$ : The error term is normally distributed.

$\mathrm{H}_{1}$ : The error term is not normally distributed.

\section{RESULTS AND DISCUSSION. Preliminary analysis}

The figure 4.1 showed the graph of exchange rate (EXC) and the return series (RT). The exchange rate from the plot was not stationary given the trending pattern it depicted in the graph. However, the return series was stationary as it was revolving around the mean as shown in the graph. Stationarity of the return series was achieved by transforming the exchange 
rate using equation (1) and the return series was found clustering round the common mean and hence indicating the presence of heteroscedasticity.

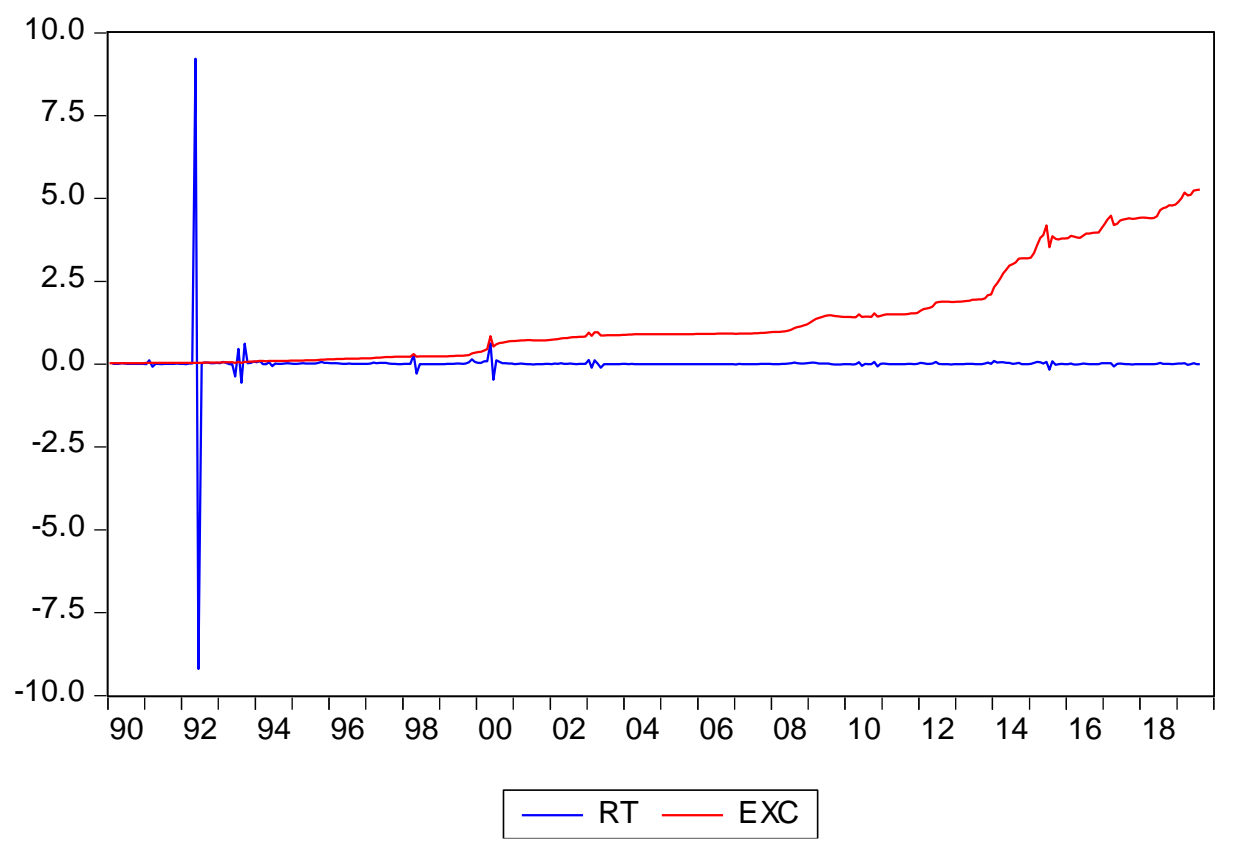

Figure 4.1: Exchange rate and its return series, Jan. 2000 to Aug. 2019

The Table 4.1 below showed the summary statistics of the daily and monthly returns on the exchange rate. From the table, the mean monthly returns was higher than the daily one with standard deviation of 0.059 and 0.0027 , respectively. Considering the distribution both returns were positively skewed and leptokurtic. Considering the Jarque-Bera statistics with the corresponding probability, the returns on exchange rate were not normally distributed.

Table 4.1: The summary statistics of the daily and monthly returns, Jan. 2000 to Aug. 2019

\begin{tabular}{|l|l|l|}
\hline & RT - daily & RT - monthly \\
\hline Mean & 0.000531 & 0.011533 \\
\hline Median & 0.00019 & 0.004204 \\
\hline Maximum & 0.037648 & 0.63255 \\
\hline Minimum & -0.02697 & -0.47086 \\
\hline Std. Dev. & 0.002698 & 0.059011 \\
\hline Skewness & 2.482421 & 2.579061 \\
\hline Kurtosis & 76.42087 & 72.28462 \\
\hline Jarque-Bera & 1157515 & 47465.15 \\
\hline Probability & 0 & 0 \\
\hline Sum & 2.721842 & 2.721842 \\
\hline Sum Sq. Dev. & 0.037333 & 0.818352 \\
\hline Observations & 5130 & 236 \\
\hline \multicolumn{3}{|l}{} \\
\hline
\end{tabular}


The results of the Augmented Dickey-Fuller unit root tests on the exchange rate was shown in Table 4.2. Considering the daily return series, the t-statistics with the corresponding probability showed that in level the null hypothesis of unit roots existing is rejected. Also, considering the monthly return series, the $\mathrm{t}$-statistics with the corresponding probability showed that in level the null hypothesis that there is a unit roots is rejected. Therefore, both daily and monthly the return series were stationary in level.

Table 4.2: ADF unit root test on exchange rate, Jan. 2000 - Aug. 2019

\begin{tabular}{|l|l|l|l|l|l|l|}
\hline & none & & constant & & cons and trend & \\
\hline & t-Statistic & Prob & t-Statistic & Prob & t-Statistic & Prob \\
\hline Daily & -10.1688 & 0 & -10.7602 & 0 & -10.7725 & 0 \\
\hline Monthly & -4.05416 & 0.0001 & -4.58659 & 0.0002 & -4.54376 & 0.0016 \\
\hline
\end{tabular}

The serial correlation test on return series for both daily and monthly data were shown in Table 4.3. From the table, lag 1, 10, 20, 30 and 36 of square residual of both series, the null hypotheses of no serial correlation were rejected. Therefore, there exist serial correlation in both return series.

Table 4.3: Serial correlation test on both return series, Jan. 2000 - Aug. 2019

\begin{tabular}{|l|l|l|l|l|l|l|l|l|}
\hline & \multicolumn{1}{|l}{ Daily } & \multicolumn{1}{l|}{ Monthly } \\
\hline Lag & AC & PAC & Q-Stat & Prob & AC & PAC & Q-Stat & Prob \\
\hline 1 & 0.127 & 0.127 & 125.19 & 0 & -0.501 & -0.501 & 89.726 & 0 \\
\hline 10 & 0.02 & 0.01 & 248.83 & 0 & 0.003 & -0.079 & 89.735 & 0 \\
\hline 20 & 0.005 & 0 & 259.72 & 0 & -0.002 & -0.046 & 92.781 & 0 \\
\hline 30 & -0.018 & -0.011 & 275.17 & 0 & 0 & -0.002 & 92.816 & 0 \\
\hline 36 & -0.031 & -0.019 & 303.84 & 0 & 0 & 0.003 & 92.818 & 0 \\
\hline
\end{tabular}

The result of Breusch-Pagan-Godfrey heteroscedasticity Test on the residual from the mean equation of $\operatorname{ARMA}(3,3)$ was shown in the table 4.4. Considering the daily return series, F-statistics (2.44) with the corresponding probability (0.04), since the p-value is less than 0.05 the null hypothesis of homoscedasticity is rejected. Considering the monthly return series, Fstatistics (7.834) with the corresponding probability (0), since the p-value is less than 0.05 the null hypothesis of homoscedasticity is rejected. Therefore, in the daily and monthly return series alternative hypothesis was accepted; that is, there is Heteroskedasticity in both series to be modelled.

Table 4.4: Heteroscedasticity test on mean equation's residual, Jan. 2000 - Aug. 2019

\begin{tabular}{|l|l|l|l|}
\hline \multicolumn{5}{|l|}{ Daily } & Monthly \\
\hline F-statistic (2.442) & Prob. F(4,5125) =0.045 & $\begin{array}{l}\text { F-statistic } \\
(7.83471)\end{array}$ & Prob. F(4,231) $=0$ \\
\hline $\begin{array}{l}\text { Obs*R-squ. } \\
(9.759)\end{array}$ & $\begin{array}{l}\text { Prob. Chi-Squ.(4) } \\
0.045\end{array}$ & $\begin{array}{l}\text { Obs*R-squ. } \\
28.19)\end{array}$ & $\left(\begin{array}{l}\text { Prob. Chi-Squ.(4) } \\
0\end{array}\right.$ \\
\hline
\end{tabular}


The results of symmetric and asymmetric GARCH models for both daily and monthly return series were shown in Table 4.5. Considering the models estimated, that is, $\operatorname{ARMA}(3,3)-\operatorname{GARCH}(2,1), \operatorname{ARMA}(3,3)-$ TARCH(2,1), ARMA(3,3)-EGARCH(2,1), $\operatorname{ARMA}(3,3)-\operatorname{PARCH}(2,1)$ and $\operatorname{ARMA}(3,3)-\operatorname{APARCH}(2,1)$, the $\operatorname{ARMA}(3,3)-\operatorname{APARCH}(2,1)-$ std with $\log$ likelihood of 44463.8 and AIC (-17.323) was best performing model and fitting the data for the daily return series and the corresponding monthly result with Log likelihood of 727.494 and AIC (-6.03809). This showed that the best model to fit this data was asymmetric model. However, there is a problem of convergence in $\operatorname{ARMA}(3,3)-\operatorname{APARCH}(2,1)$-std when the variance is introduced to the mean equation, therefore, the second best asymmetric model ARMA(3,3)-TARCH(2,1)-GED with log likelihood of 43197.3 with AIC (16.84) for the daily return series and the corresponding monthly result with Log likelihood of 706.465 and AIC (-5.868) will be used instead. Therefore, the ARMA(3,3)-TARCH(2,1)-GED was the appropriate model selected for the examination of the effect of serial correlation on the parameters estimated.

Table 4.5: Result of GARCH models and model selection

\begin{tabular}{|c|c|c|c|c|c|c|c|c|}
\hline & Daily & & & & Monthly & & & \\
\hline $\operatorname{GARCH}(1,2)$ & $\begin{array}{l}\text { student } \\
\mathrm{t}\end{array}$ & & & & & & & \\
\hline Variable & Coeff & $\begin{array}{l}\text { Std. } \\
\text { Error }\end{array}$ & $\begin{array}{l}\mathrm{Z}- \\
\text { Statistic }\end{array}$ & Prob. & Coeff & $\begin{array}{l}\text { Std. } \\
\text { Error }\end{array}$ & $\begin{array}{l}\text { Z- } \\
\text { Statistic }\end{array}$ & Prob. \\
\hline $\mathrm{C}$ & 0.0000 & 0.0000 & 0.1080 & 0.9140 & 0.0005 & 0.0015 & 0.3315 & 0.7403 \\
\hline @TREND & 0.0000 & 0.0000 & 0.1108 & 0.9118 & 0.0000 & 0.0000 & 0.3405 & 0.7335 \\
\hline $\mathrm{RT}(-1)$ & 0.9737 & 10.405 & 0.0936 & 0.9254 & -0.0613 & 0.5908 & -0.1038 & 0.9173 \\
\hline RT(-2) & 0.0198 & 12.339 & 0.0016 & 0.9987 & 0.6305 & 0.0477 & 13.2123 & 0.0000 \\
\hline RT(-3) & 0.0001 & 3.5963 & 0.0000 & 1.0000 & 0.0743 & 0.3912 & 0.1899 & 0.8494 \\
\hline MA(1) & -0.0014 & 10.321 & -0.0001 & 0.9999 & 0.3683 & 0.5780 & 0.6372 & 0.5240 \\
\hline $\mathrm{MA}(2)$ & -0.0012 & 3.6355 & -0.0003 & 0.9997 & -0.4312 & 0.2085 & -2.0680 & 0.0386 \\
\hline MA(3) & 0.0083 & 0.2109 & 0.0393 & 0.9686 & -0.0838 & 0.2621 & -0.3199 & 0.7491 \\
\hline & \multicolumn{4}{|c|}{ Variance Equation } & & \multicolumn{3}{|c|}{ Variance Equation } \\
\hline $\mathrm{C}$ & 0.0000 & 0.0000 & 32.3713 & 0.0000 & 0.0000 & 0.0000 & 3.5992 & 0.0003 \\
\hline $\operatorname{RESID}(-1)^{\wedge} 2$ & 0.2843 & 0.0240 & 11.8296 & 0.0000 & 0.9742 & 0.3101 & 3.1411 & 0.0017 \\
\hline GARCH(-1) & 0.4223 & 0.0211 & 20.0000 & 0.0000 & 0.1343 & 0.0542 & 2.4802 & 0.0131 \\
\hline \multirow[t]{2}{*}{ GARCH(-2) } & -0.0498 & 0.0042 & -11.7937 & 0.0000 & -0.0106 & 0.0047 & -2.2669 & 0.0234 \\
\hline & AIC & -16.62 & Loglik & $\begin{array}{l}42655 . \\
7 \\
\end{array}$ & AIC & -5.6378 & Loglik & 678.26 \\
\hline TARCH(2,1) & GED & & & & & & & \\
\hline Variable & Coeff & $\begin{array}{l}\text { Std. } \\
\text { Error }\end{array}$ & $\begin{array}{l}\text { z- } \\
\text { Statistic }\end{array}$ & Prob. & Coeff & $\begin{array}{l}\text { Std. } \\
\text { Error }\end{array}$ & $\begin{array}{l}\text { z- } \\
\text { Statistic }\end{array}$ & Prob. \\
\hline $\mathrm{C}$ & 0.0000 & 0.0000 & -4.5794 & 0.0000 & 0.0000 & 0.0002 & 0.2154 & 0.8295 \\
\hline @TREND & 0.0000 & 0.0000 & 13.3659 & 0.0000 & 0.0000 & 0.0000 & 0.8774 & 0.3803 \\
\hline RT(-1) & 0.9888 & 0.0267 & 37.1003 & 0.0000 & 0.2719 & 0.0651 & 4.1748 & 0.0000 \\
\hline RT(-2) & -0.0329 & 0.0274 & -1.1968 & 0.2314 & 0.4504 & 0.0233 & 19.3666 & 0.0000 \\
\hline RT $(-3)$ & 0.0223 & 0.0061 & 3.6657 & 0.0002 & -0.0055 & 0.0308 & -0.1790 & 0.8579 \\
\hline MA(1) & -0.0028 & 0.0259 & -0.1091 & 0.9131 & -0.0009 & 0.0522 & -0.0175 & 0.9860 \\
\hline MA(2) & 0.1084 & 0.0052 & 21.0494 & 0.0000 & -0.4098 & 0.0233 & 17.5775 & 0.0000 \\
\hline $\mathrm{MA}(3)$ & 0.0497 & 0.0027 & 18.4627 & 0.0000 & -0.0533 & 0.0213 & -2.5024 & 0.0123 \\
\hline
\end{tabular}




\begin{tabular}{|c|c|c|c|c|c|c|c|c|}
\hline \multirow[b]{2}{*}{$\mathrm{C}$} & \multicolumn{4}{|c|}{ Variance Equation } & \multicolumn{4}{|c|}{ Variance Equation } \\
\hline & 0.0000 & 0.0000 & 55.2877 & 0.0000 & 0.0000 & 0.0000 & 2.4122 & 0.0159 \\
\hline $\operatorname{RESID}(-1)^{\wedge} 2$ & 1.1322 & 0.0364 & 31.1046 & 0.0000 & 3.7806 & 1.4635 & 2.5832 & 0.0098 \\
\hline $\begin{array}{l}\text { RESID }(- \\
1)^{\wedge} 2 *(\text { RESID }(- \\
1)<0)\end{array}$ & 0.1389 & 0.0451 & 3.0810 & 0.0021 & -2.1710 & 1.5026 & -1.4448 & 0.1485 \\
\hline $\operatorname{RESID}(-2)^{\wedge} 2$ & 0.0568 & 0.0077 & 7.3747 & 0.0000 & -0.7619 & 0.7068 & -1.0779 & 0.2811 \\
\hline \multirow[t]{2}{*}{ GARCH(-1) } & -0.0421 & 0.0065 & -6.5054 & 0.0000 & 0.3583 & 0.1471 & 2.4350 & 0.0149 \\
\hline & AIC & -16.84 & Loglik & $\begin{array}{l}43197 . \\
3\end{array}$ & AIC & -5.868 & Loglik & 706.465 \\
\hline $\operatorname{EGARCH}(2,2)$ & $\begin{array}{l}\text { student } \\
\mathrm{t}\end{array}$ & & & & & & & \\
\hline Variable & Coeff & $\begin{array}{l}\text { Std. } \\
\text { Error }\end{array}$ & $\begin{array}{l}\mathrm{z}- \\
\text { Statistic }\end{array}$ & Prob. & Coeff & $\begin{array}{l}\text { Std. } \\
\text { Error }\end{array}$ & $\begin{array}{l}\mathrm{z}- \\
\text { Statistic }\end{array}$ & Prob. \\
\hline $\mathrm{C}$ & -0.0001 & 0.0000 & -1.2946 & 0.1955 & 0.0023 & 0.0001 & 21.5774 & 0.0000 \\
\hline @TREND & 0.0000 & 0.0000 & 1.3166 & 0.1880 & 0.0000 & 0.0000 & -3.1182 & 0.0018 \\
\hline $\mathrm{RT}(-1)$ & 0.5768 & 0.5978 & 0.9648 & 0.3347 & 0.8055 & 0.0711 & 11.3333 & 0.0000 \\
\hline RT(-2) & 0.0563 & 0.4114 & 0.1368 & 0.8912 & 0.4624 & 0.0676 & 6.8438 & 0.0000 \\
\hline RT(-3) & 0.0350 & 0.3210 & 0.1091 & 0.9131 & -0.4767 & 0.0530 & -8.9930 & 0.0000 \\
\hline $\mathrm{MA}(1)$ & 0.1497 & 0.6101 & 0.2454 & 0.8061 & -0.6373 & 0.0787 & -8.0974 & 0.0000 \\
\hline $\mathrm{MA}(2)$ & 0.0178 & 0.4251 & 0.0420 & 0.9665 & -0.4522 & 0.0495 & -9.1354 & 0.0000 \\
\hline \multirow[t]{2}{*}{$\mathrm{MA}(3)$} & 0.0302 & 0.0501 & 0.6022 & 0.5470 & 0.4452 & 0.0539 & 8.2551 & 0.0000 \\
\hline & \multicolumn{4}{|c|}{ Variance Equation } & \multicolumn{4}{|c|}{ Variance Equation } \\
\hline $\mathrm{C}(9)$ & -7.1216 & 0.2043 & -34.8621 & 0.0000 & -2.7018 & 0.3645 & -7.4115 & 0.0000 \\
\hline $\mathrm{C}(10)$ & 0.7882 & 0.0289 & 27.2273 & 0.0000 & 0.1198 & 0.0580 & 2.0659 & 0.0388 \\
\hline $\mathrm{C}(11)$ & 1.3460 & 0.0339 & 39.6801 & 0.0000 & -0.0882 & 0.0651 & -1.3558 & 0.1752 \\
\hline $\mathrm{C}(12)$ & 0.1537 & 0.0101 & 15.2763 & 0.0000 & 0.5652 & 0.0563 & 10.0430 & 0.0000 \\
\hline $\mathrm{C}(13)$ & 0.0939 & 0.0267 & 3.5135 & 0.0004 & 0.6526 & 0.0503 & 12.9733 & 0.0000 \\
\hline \multirow[t]{2}{*}{$\mathrm{C}(14)$} & 0.5370 & 0.0235 & 22.8736 & 0.0000 & 0.0577 & 0.0248 & 2.3297 & 0.0198 \\
\hline & AIC & 13.554 & Loglik & $\begin{array}{l}34781 . \\
6\end{array}$ & AIC & -5.015 & Loglik & 606.8 \\
\hline $\operatorname{PARCH}(2,1)$ & $\begin{array}{l}\text { student } \\
\mathrm{t}\end{array}$ & & & & & & & \\
\hline Variable & Coeff & $\begin{array}{l}\text { Std. } \\
\text { Error }\end{array}$ & $\begin{array}{l}\text { z- } \\
\text { Statistic }\end{array}$ & Prob. & Coeff & $\begin{array}{l}\text { Std. } \\
\text { Error }\end{array}$ & $\begin{array}{l}\text { z- } \\
\text { Statistic }\end{array}$ & Prob. \\
\hline $\mathrm{C}$ & 0.0000 & 0.0000 & -9.8450 & 0.0000 & -0.0010 & 0.0002 & -6.4469 & 0.0000 \\
\hline @TREND & 0.0000 & 0.0000 & 10.5160 & 0.0000 & 0.0000 & 0.0000 & 6.9439 & 0.0000 \\
\hline RT(-1) & 0.9988 & 0.1314 & 7.5993 & 0.0000 & 0.6992 & 0.0703 & 9.9406 & 0.0000 \\
\hline RT(-2) & 0.0085 & 0.1729 & 0.0493 & 0.9607 & 0.4177 & 0.0682 & 6.1252 & 0.0000 \\
\hline RT(-3) & -0.0279 & 0.0439 & -0.6350 & 0.5254 & -0.2397 & 0.0295 & -8.1380 & 0.0000 \\
\hline $\mathrm{MA}(1)$ & 0.1780 & 0.1309 & 1.3605 & 0.1737 & -0.2849 & 0.0698 & -4.0786 & 0.0000 \\
\hline $\mathrm{MA}(2)$ & 0.0153 & 0.0201 & 0.7645 & 0.4446 & -0.5090 & 0.0473 & 10.7641 & 0.0000 \\
\hline \multirow[t]{2}{*}{ MA(3) } & 0.0085 & 0.0030 & 2.8295 & 0.0047 & 0.0465 & 0.0138 & 3.3626 & 0.0008 \\
\hline & \multicolumn{4}{|c|}{ Variance Equation } & \multicolumn{4}{|c|}{ Variance Equation } \\
\hline $\mathrm{C}(9)$ & 0.0000 & 0.0000 & 2.9205 & 0.0035 & 0.0232 & 0.0221 & 1.0485 & 0.2944 \\
\hline $\mathrm{C}(10)$ & 1.1940 & 0.0194 & 61.4268 & 0.0000 & 0.7186 & 0.2309 & 3.1124 & 0.0019 \\
\hline $\mathrm{C}(11)$ & -0.0348 & 0.2138 & -0.1629 & 0.8706 & -0.5390 & 0.2099 & -2.5678 & 0.0102 \\
\hline $\mathrm{C}(12)$ & 0.0308 & 0.1764 & 0.1747 & 0.8613 & 0.8180 & 0.1048 & 7.8038 & 0.0000 \\
\hline \multirow[t]{2}{*}{$\mathrm{C}(13)$} & 1.0398 & 0.0227 & 45.7814 & 0.0000 & 0.1912 & 0.1723 & 1.1101 & 0.2669 \\
\hline & AIC & -17.11 & Loglik & $\begin{array}{l}43912 . \\
5\end{array}$ & $\mathrm{AIC}$ & -5.846 & Loglik & 703.81 \\
\hline
\end{tabular}




\begin{tabular}{|c|c|c|c|c|c|c|c|c|}
\hline $\operatorname{APARCH}(2,1)$ & $\begin{array}{l}\text { student } \\
\mathrm{t}\end{array}$ & & & & & & & \\
\hline Variable & Coeff & $\begin{array}{l}\text { Std. } \\
\text { Error }\end{array}$ & $\begin{array}{l}\mathrm{z}- \\
\text { Statistic }\end{array}$ & Prob. & Coeff & $\begin{array}{l}\text { Std. } \\
\text { Error }\end{array}$ & $\begin{array}{l}\mathrm{z}- \\
\text { Statistic }\end{array}$ & Prob. \\
\hline $\mathrm{C}$ & 0.0000 & 0.0000 & 0.4782 & 0.6325 & 0.0002 & 0.0002 & 0.9193 & 0.3579 \\
\hline @TREND & 0.0000 & 0.0000 & 0.4544 & 0.6495 & 0.0000 & 0.0000 & -0.4974 & 0.6189 \\
\hline RT(-1) & 1.0209 & 0.4909 & 2.0798 & 0.0375 & 0.7740 & 0.1260 & 6.1414 & 0.0000 \\
\hline RT(-2) & 0.0058 & 0.5390 & 0.0107 & 0.9914 & 0.3988 & 0.1001 & 3.9821 & 0.0001 \\
\hline RT(-3) & -0.0288 & 0.0638 & -0.4512 & 0.6518 & -0.3024 & 0.0538 & -5.6222 & 0.0000 \\
\hline MA(1) & 0.0668 & 0.4910 & 0.1360 & 0.8919 & -0.3090 & 0.1252 & -2.4692 & 0.0135 \\
\hline MA(2) & -0.0230 & 0.0430 & -0.5339 & 0.5934 & -0.5074 & 0.0693 & -7.3249 & 0.0000 \\
\hline MA(3) & -0.0019 & 0.0039 & -0.4903 & 0.6239 & 0.0705 & 0.0332 & 2.1228 & 0.0338 \\
\hline & \multicolumn{4}{|c|}{ Variance Equation } & \multicolumn{4}{|c|}{ Variance Equation } \\
\hline$C(9)$ & 0.0000 & 0.0000 & 1.7807 & 0.0750 & 0.0021 & 0.0017 & 1.2074 & 0.2273 \\
\hline $\mathrm{C}(10)$ & 0.6857 & 0.0372 & 18.4393 & 0.0000 & 1.0760 & 0.3620 & 2.9722 & 0.0030 \\
\hline $\mathrm{C}(11)$ & 0.0378 & 0.0187 & 2.0172 & 0.0437 & -0.2015 & 0.0843 & -2.3910 & 0.0168 \\
\hline $\mathrm{C}(12)$ & 0.1534 & 0.0154 & 9.9515 & 0.0000 & -1.1429 & 0.3580 & -3.1930 & 0.0014 \\
\hline $\mathrm{C}(13)$ & -0.0355 & 0.0003 & $\begin{array}{l}119.110 \\
0\end{array}$ & 0.0000 & 1.0009 & 0.0299 & 33.4440 & 0.0000 \\
\hline $\mathrm{C}(14)$ & 1.3818 & 0.0452 & 30.5898 & 0.0000 & 0.5371 & 0.1390 & 3.8649 & 0.0001 \\
\hline & AIC & -17.32 & AIC & 44464 & AIC & -6.038 & Loglik & 727.5 \\
\hline
\end{tabular}

NB: AIC - Akaike info criterion; Loglik - Log likelihood

The evaluation of serial correlation for the selected model and the corresponding GARCH-M estimates were shown in Table 4.6. From the table, the $5,20,30$ and $36^{\text {th }}$ lags were considered. The correlogram of square residual of $\operatorname{ARMA}(3,3)$-TARCH$(2,1)$-GED showed that the null hypothesis of no serial correlation existing among the residuals was accepted for both daily and monthly residual. Considering the corresponding GARCH-M estimates, the correlogram of square residual showed that the null hypothesis of no serial correlation existing among the residuals was accepted for both daily and monthly residual. Therefore, there is no serial correlation existing among the residuals of the model selected and the corresponding GARCH-M.

Table 4.6: Evaluation of serial correlation for selected model and its GARCH-M, Jan. 2000 -

Aug. 2019

\begin{tabular}{|l|l|l|l|l|l|l|l|l|l|l|}
\hline None & Lag & \multicolumn{1}{l}{ Daily } & \multicolumn{1}{l|}{ Lag } & \multicolumn{2}{l|}{ Monthly } \\
\hline & 5 & -0.001 & -0.001 & 0.0191 & 0.99 & 5 & -0.018 & -0.022 & 0.8354 & 0.361 \\
\hline & 20 & 0.008 & 0.008 & 0.4115 & 1 & 20 & -0.002 & 0.009 & 28.039 & 0.083 \\
\hline & 30 & 0.004 & 0.004 & 0.4779 & 1 & 30 & -0.023 & -0.005 & 29.225 & 0.35 \\
\hline & 36 & 0.023 & 0.023 & 3.1463 & 1 & 36 & -0.014 & -0.005 & 32.702 & 0.482 \\
\hline GARCH-M & & Daily & & & & & Monthly & & & \\
\hline & 5 & -0.001 & -0.001 & 0.0218 & 0.989 & 5 & 0.112 & 0.111 & 3.334 & 0.189 \\
\hline & 20 & 0.011 & 0.01 & 0.6511 & 1 & 20 & 0.002 & -0.001 & 3.8146 & 1 \\
\hline & 30 & 0.004 & 0.004 & 0.7552 & 1 & 30 & -0.009 & -0.01 & 4.1814 & 1 \\
\hline & 36 & 0.025 & 0.025 & 3.9105 & 1 & 36 & -0.01 & -0.01 & 4.6716 & 1 \\
\hline
\end{tabular}


The evaluation of heteroscedasticity of the residual the selected models and the corresponding GARCH-M estimates were shown in Table 4.7. From the table, the ARCH test on residual of TARCH showed that null hypothesis of homoscedasticity is not rejected for both daily and monthly output. Considering the corresponding GARCH-M estimates, the ARCH test on residual of TARCH showed that null hypothesis of homoscedasticity is not rejected for both daily and monthly output. Therefore, the residuals of the estimated models were homoscedastic.

Table 4.7: ARCH-LM Heteroskedasticity Test for selected model and its GARCH-M, Jan. 2000 - Aug. 2019

\begin{tabular}{|l|l|l|l|l|l|l|}
\hline None & Daily & & & Monthly & & \\
\hline TARCH & $\begin{array}{l}\text { F- } \\
\text { statistic }\end{array}$ & 0.00435 & Prob. F $(1,5127)=0.9474$ & F-statistic & 0.1938 & Prob. $\mathrm{F}(1,233)=0.6602$ \\
\hline & $\begin{array}{l}\text { Obs*R- } \\
\text { squ. }\end{array}$ & 0.00435 & Prob. Chi-Squ. $=0.9474$ & Obs*R-squ. & 0.1953 & Prob. Chi-Squ. $=0.6586$ \\
\hline GARCH-M & $\begin{array}{l}\text { F- } \\
\text { statistic }\end{array}$ & 0.00379 & Prob. F $(1,5127)=0.9509$ & F-statistic & 0.0290 & Prob. F $(1,233)=0.865$ \\
\hline TARCH & $\begin{array}{l}\text { Obs*R- } \\
\text { squ. }\end{array}$ & 0.00379 & Prob. Chi-Squ. $=0.9509$ & Obs*R-squ. & 0.0292 & Prob. Chi-Squ. $=0.8643$ \\
\hline
\end{tabular}

The result of the asymmetric GARCH-M ARMA(3,3)-TARCH(2,1)GED for the daily and monthly estimations were shown in Table 4.8. Considering the daily result, from the table, all the parameters of the estimate were significant at 5\% level of significance except $\operatorname{AR}(2), \operatorname{AR}(3), \operatorname{MA}(1)$, MA(1) terms and second day's information about volatility. The coefficient of the GARCH-M was 1.15E-05 with p-value of zero which shows that GARCH$M$ coefficient is significance. This confirmed the presence of serial correlation in the return series as shown by the correlogram in Table 4.4. This showed that daily volatility increased future returns on the daily exchange rate, therefore, lower daily volatility will help stabilize daily exchange rate. From the table, the previous day's one and day two information about volatility had 0.14 units and -0.09 unit effect on current day's volatility but the second day's effect was not significant. Also, the previous day's volatility had 0.5 unit effect on the current day volatility. The asymmetric coefficient was -0.089 unit with p-value of zero which shows that the coefficient was significance. Since, the coefficient was negative it showed that bad news decreased volatility, hence, there is no leverage effect. The good news had an impact of $\alpha_{i}=(0.1434-$ $0.0042)=0.1392$ unit on current day's volatility while bad news has an impact of $\alpha_{i}+\lambda_{j}=(0.1392-0.0890)=0.0502$ on current day's volatility. Also, as $\lambda$ was significantly different from zero, this implied that the impact of news is asymmetric.

Considering the monthly result, from the table, all the parameters of the estimate were significant at 5\% level of significance except AR(3) and 
previous second month's information about volatility. The coefficient of the GARCH-M is -0.045 unit with p-value of zero which show that the coefficient was significance. This also confirmed the presence of serial correlation in the return series as shown by the correlogram in table 4.4. This showed that monthly volatility decreased future returns on the monthly exchange rate. From the table, the previous first month's and second month's information about volatility had 0.14 unit and 0.006 unit effect on current month's volatility. Also, the previous month's volatility had 0.119 unit effect on the current day volatility. The asymmetric coefficient was -0.1803 unit with $\mathrm{p}$ value of zero which shows that the coefficient was significance. Since, the coefficient was negative it showed that bad news decreased volatility hence there is no leverage effect. The good news had an impact of $\alpha_{i}=(0.1416-$ $0.0061)=0.1355$ unit on current day's volatility while bad news had an impact of $\left.\alpha_{i}+\lambda_{j}=0.1355-0.1803\right)=-0.0448$ on current day's volatility. Also, as $\lambda$

was significantly different from zero, this implied that the impact of news is asymmetric.

Table 4.8: Modeling GARCH-M-TARCH Processes on return series, Jan. 2000-Aug. 2019

\begin{tabular}{|c|c|c|c|c|c|c|c|c|}
\hline & Daily & & & & Monthly & & & \\
\hline Variable & Coeff & Std. Error & z-Stat & Prob. & Coefficient & Std. Error & z-Statistic & Prob. \\
\hline LOG(GARCH) & $1.2 \mathrm{E}-05$ & $2.5 \mathrm{E}-06$ & 4.62 & 0 & -0.0446 & 0.0096 & -4.6538 & 0 \\
\hline $\mathrm{C}$ & $2.4 \mathrm{E}-04$ & $5.2 \mathrm{E}-05$ & 4.55 & 0 & -0.3365 & 0.0710 & -4.7384 & 0 \\
\hline @ TREND & $8.7 \mathrm{E}-10$ & $3.9 \mathrm{E}-10$ & 2.24 & 0.0253 & 0.0000 & 0.0000 & 11.1033 & 0 \\
\hline $\mathrm{AR}(-1)$ & $1.0 \mathrm{E}+00$ & $1.6 \mathrm{E}-01$ & 6.48 & 0 & -0.4333 & 0.0359 & -12.0616 & 0 \\
\hline $\operatorname{AR}(-2)$ & $1.2 \mathrm{E}-02$ & $2.3 \mathrm{E}-01$ & 0.05 & 0.9573 & 0.3098 & 0.0130 & 23.8923 & 0 \\
\hline AR (-3) & $-7.5 \mathrm{E}-02$ & $8.3 \mathrm{E}-02$ & -0.90 & 0.3675 & -0.0095 & 0.0180 & -0.5287 & 0.597 \\
\hline MA(1) & $9.8 \mathrm{E}-02$ & $1.6 \mathrm{E}-01$ & 0.62 & 0.5329 & 0.7380 & 0.0284 & 25.9889 & 0 \\
\hline $\mathrm{MA}(2)$ & $8.4 \mathrm{E}-02$ & $6.3 \mathrm{E}-02$ & 1.34 & 0.1812 & 0.1955 & 0.0212 & 9.2380 & 0 \\
\hline $\mathrm{MA}(3)$ & $8.2 \mathrm{E}-02$ & $2.0 \mathrm{E}-02$ & 4.19 & 0 & 0.2391 & 0.0119 & 20.1658 & 0 \\
\hline & \multicolumn{4}{|c|}{ Variance Equation } & \multicolumn{4}{|c|}{ Variance Equation } \\
\hline $\bar{C}$ & $2.0 \mathrm{E}-09$ & $1.3 \mathrm{E}-10$ & 14.64 & 0 & 0.0011 & $6.8 \mathrm{E}-05$ & 16.4180 & 0 \\
\hline $\operatorname{RESID}(-1)^{\wedge} 2$ & $1.4 \mathrm{E}-01$ & $1.7 \mathrm{E}-02$ & 8.65 & 0 & 0.1416 & $3.4 \mathrm{E}-02$ & 4.1392 & 0 \\
\hline $\operatorname{RESID}(-1)^{\wedge} 2^{*}(\operatorname{RESID}(-1)<0)$ & $-8.9 \mathrm{E}-02$ & $1.1 \mathrm{E}-02$ & -8.40 & 0 & -0.1803 & $4.2 \mathrm{E}-02$ & -4.2860 & 0 \\
\hline $\operatorname{RESID}(-2)^{\wedge} 2$ & $-4.3 \mathrm{E}-03$ & $2.0 \mathrm{E}-02$ & -0.21 & 0.8333 & 0.0061 & $4.2 \mathrm{E}-03$ & 1.4688 & 0.1419 \\
\hline GARCH(-1) & $5.0 \mathrm{E}-01$ & $3.3 \mathrm{E}-02$ & 15.31 & 0 & 0.1192 & $5.0 \mathrm{E}-02$ & 2.3657 & 0.018 \\
\hline & AIC & -15.898 & Loglik & 40793.7 & AIC & -5.2666 & Loglik & 636.46 \\
\hline
\end{tabular}

\section{Effects on the parameters}

The table 4.9 showed possible biases that were introduced into the parameters of the ARMA(3,3)-TARCH(2,1)-GED model for daily and monthly estimates when the possible existence of serial correlation was ignored. Considering the daily result, if serial correlations were ignored, the constant term of the mean equation, $\operatorname{AR}(2), \operatorname{AR}(3)$, $\mathrm{MA}(2)$ and $\mathrm{MA}(3)$ terms, asymmetric coefficient, $\mathrm{ARCH}(2)$ and $\mathrm{GARCH}(1)$ were reduced by $0.0002,0.0035,0.2365,0.1516,0.0740,0.0808$ and 0.0619 , respectively, while AR(1), MA(1) and ARCH(1) terms were inflated by $0.2589,0.1046$ and 0.1489 , 
respectively. Considering the monthly result, if serial correlations were ignored, MA(1), MA(2) and MA(3) terms, constant term of the variance equation, asymmetric coefficient and $\mathrm{ARCH}(2)$ were reduced by $0.7389,0.6054,0.2923,0.0011,1.9906$ and 0.7680, respectively, while constant term of the mean equation, $\operatorname{AR}(1), \operatorname{AR}(2), \operatorname{AR}(3)$, $\mathrm{ARCH}(1)$ term and $\mathrm{GARCH}(1)$ were inflated by $0.3365,0.7051,0.1406,0.0040$, 3.6390 and 0.2391 , respectively. In sum, ignoring serial correlations in the return series made parameter estimated bias and efficient. This confirmed Moffat, I., \& Akpan, E. (2019) who concluded that GARCH-in-Mean-EGARCH(1,1) model under student-t distribution sufficiently appraised the existence of serial correlations.

Table 4.9: Bias cause by the existence of serial correlation on parameters

\begin{tabular}{|l|l|l|l|l|l|l|}
\hline & $\begin{array}{l}\text { ARMA(3,3)- } \\
\text { APARCH(2,1) }\end{array}$ & $\begin{array}{l}\text { ARMA(3,3)- } \\
\text { APARCH(2,1) }\end{array}$ & ARMA(3,3)- & $\begin{array}{l}\text { ARMA(3,3)- } \\
\text { APARCH(2,1 } \\
\text { APARCH(2, }\end{array}$ & Bias \\
\hline & & & & & & \\
\hline $\begin{array}{l}\text { LOG(G } \\
\text { ARCH) }\end{array}$ & & $1.15 \mathrm{E}-05$ & & & -0.044615 & \\
\hline C & $9.74 \mathrm{E}-07$ & 0.000238 & -0.0002 & $4.61 \mathrm{E}-05$ & -0.336498 & 0.3365 \\
\hline $\begin{array}{l}\text { @ TREN } \\
\text { D }\end{array}$ & $1.61 \mathrm{E}-10$ & $8.69 \mathrm{E}-10$ & 0.0000 & $8.49 \mathrm{E}-07$ & $3.15 \mathrm{E}-05$ & 0.0000 \\
\hline AR(-1) & 1.290626 & 1.031762 & 0.2589 & 0.271859 & -0.433286 & 0.7051 \\
\hline AR (-2) & 0.009012 & 0.012488 & -0.0035 & 0.450411 & 0.30978 & 0.1406 \\
\hline AR (-3) & -0.311399 & -0.074943 & -0.2365 & -0.005514 & -0.009515 & 0.0040 \\
\hline MA(1) & 0.202239 & 0.097654 & 0.1046 & -0.000915 & 0.738013 & -0.7389 \\
\hline MA(2) & -0.067242 & 0.084335 & -0.1516 & -0.409844 & 0.195536 & -0.6054 \\
\hline MA(3) & 0.008394 & 0.082373 & -0.0740 & -0.053257 & 0.239083 & -0.2923 \\
\hline & & & & & & -0.0011 \\
\hline C & $6.24 \mathrm{E}-10$ & $1.95 \mathrm{E}-09$ & 0.0000 & $3.22 \mathrm{E}-05$ & 0.001124 & 3.6390 \\
\hline $\begin{array}{l}\text { RESID(- } \\
1)^{\wedge} 2\end{array}$ & 0.292326 & 0.143412 & 0.1489 & 3.780556 & 0.141568 & \\
\hline $\begin{array}{l}\text { RESID(- } \\
1)^{\wedge} 2 *(\mathrm{R}\end{array}$ & -0.169793 & -0.089041 & & -2.170952 & -0.180334 & \\
$\begin{array}{l}\text { ESID(- } \\
1)<0)\end{array}$ & & -0.004254 & -0.0619 & -0.76187 & 0.006146 & -0.7680 \\
\hline $\begin{array}{l}\text { RESID(- } \\
2)^{\wedge} 2\end{array}$ & -0.0662 & 0.499887 & -0.1628 & 0.358267 & 0.119183 & 0.2391 \\
\hline $\begin{array}{l}\text { GARCH } \\
(-1)\end{array}$ & 0.337137 & & & & \\
\hline
\end{tabular}

\section{Summary and Conclusion}

The main objective of this paper was to model the exchange rate volatility of the GHC/US\$ series in the presence of serial correlations. The data used was daily and monthly average effective exchange rate, GHC-US\$, from January 2000 to August 2019. Based on the evaluation, the $\operatorname{ARMA}(3,3)$ TARCH(2,1)-GED was the appropriate model selected for the examination of the effect of serial correlation on the parameters estimated. The correlogram of the return series showed that serial correlation exist in the return series. The findings showed that heteroscedasticity exists and appeared to be adequately captured by $\operatorname{ARMA}(3,3)-\mathrm{TARCH}(2,1)$ model under general error distribution 
but failed to account for the presence of serial correlations in the return series. But the corresponding GARCH-M-TARCH(2,1) model under general error distribution sufficiently appraised the existence of serial correlations. From the results when the existence of serial correlations were ignored in the return series the parameters estimated will be bias and inefficient. Hence, the application of GARCH-M-GARCH-type model possibly provides the feedback mechanism or interaction between the variance and mean equations. It was also found out that previous information about volatility and the previous volatility had significant effect on the current day volatility. From the result there was no leverage effect and the impact of news was asymmetric.

Therefore, it is recommended that the existence of serial correlation in the financial variables should not be ignored when modelling volatility. Also, the central bank should put measures in place to stabilize the cedi since increase impacted on the future return on the GHC/US\$ exchange rate. For further study, other researchers can also consider the weekly or the yearly exchange rate and examine the issues of volatility, serial correlations and its impact on the parameter estimate.

\section{References:}

1. Abdullah, S. M., Siddiqua, S., Siddiquee, M. S. H., \& Hossain, N. (2017). Modeling and forecasting exchange rate volatility in Bangladesh using GARCH models: a comparison based on normal and Student's t-error distribution. Financial Innovation, 3(1), 18.

2. Alam, M. Z. (2012). Modelling volatility of the BDT/USD exchange rate with GARCH Model. International Journal of Economics and Finance, 4(11), 193.

3. Bollerslev, T. (1986). Generalized autoregressive conditional heteroscedasticity, Journal of Econometrics, 9(2), 121-131.

4. Clement, A., \& Samuel, A. (2011). Empirical modeling of Nigerian exchange rate volatility. Math Theory Model, 1(3), 8-15.

5. Glosten, L.R. Jagannathan, R. \& Runkle, D.E. (1993). Relationship between the expected value and the volatility of the nominal excess return on stocks, The Journal of Finance, 48(5), 1779-1801.

6. Engle, R.F., Lilien, D.M. \& Robin, R.P. (1987). Estimating Time Varying Risk Premia in the Term Structure: The Arch-M Model. Econometrica; 55(2): 391-407.

7. Government of Ghana. Bank of Ghana Monetary time series. www.bog.gov.gh

8. Moffat, I., \& Akpan, E. (2019). Modeling Heteroscedasticity in the Presence of Serial Correlations in Discrete-time Stochastic Series: A GARCH-in-Mean Approach. Asian Journal of Probability and Statistics, 4(2), 1-16. 
9. Mathur S., Chotia, V. \& Rao, N.V.M. (2016). Modeling the Impact of Global Financial Crisis on the Indian Stock Market through GARCH Models. Asia-Pacific Journal of Management Research and Innovation; 12(1): 11-12.

10. Nelson, D. B. (1991). Conditional Heteroskedasticity in Asset Returns: A New Approach. Econometrica, 59, 347-370.

11. Ramasamy, R., \& Munisamy, S. (2012). Predictive accuracy of GARCH, GJR and EGARCH models select exchange rates application. Global Journal of Management and Business Research, 12(15).

12. Schwert, W. (1989). Stock Volatility and Crash of '87. Review of Financial Studies, 3, 77-102.

13. Taylor, S. J. (1986). Modelling Financial Time Series. Wiley, Chichester.

14. Tsay RS. (2010). Analysis of Financial Time Series. 3rd ed. New York: John Wiley \& Sons Inc., pp 97-140.

15. Tse, Y.K. (1998). The conditional heteroscedasticity of Japanese Yen to US dollar exchange rate. Journal of Econometrics, 13(1), 49-55

16. Zakoan, J.M. (1994). Threshold heteroscedasticity models. Journal of Economic Dynamics and Control, 18(5), 931-955.

17. Zhao, H, Huffer, F. and Niu, X. (2014). Time-Varying Coefficient Models with ARMA-GARCH Structures for Longitudinal Data Analysis. Journal of Applied Statistics; 42(2):309-326. 